\title{
Effects of Prenatal and Perinatal Exposure to Fine Air Pollutants and Maternal Fish Consumption on the Occurrence of Infantile Eczema
}

\author{
Wieslaw Jedrychowski ${ }^{a}$ Frederica Perera ${ }^{b}$ Umberto Maugeri ${ }^{\mathrm{e}}$ \\ Dorota Mrozek-Budzyn $^{a}$ Rachel L. Miller ${ }^{b, c}$ Elzbieta Flak ${ }^{a}$ Elzbieta Mroz ${ }^{a}$ \\ Ryszard Jacek $^{\mathrm{a}}$ John D. Spengler ${ }^{\mathrm{d}}$ \\ ${ }^{\text {a } D e p a r t m e n t ~ o f ~ E p i d e m i o l o g y ~ a n d ~ P r e v e n t i v e ~ M e d i c i n e, ~ J a g i e l l o n i a n ~ U n i v e r s i t y ~ M e d i c a l ~ C o l l e g e, ~ K r a k o w, ~ P o l a n d ; ~}$ \\ ${ }^{b}$ Center for Children's Environmental Health, Mailman School of Public Health, Columbia University, New York, \\ N.Y., 'Division of Pulmonary, Allergy and Critical Care Medicine, Columbia University College of Physicians and \\ Surgeons, New York, N.Y., and d Department of Environmental Health, School of Public Health, Harvard University,

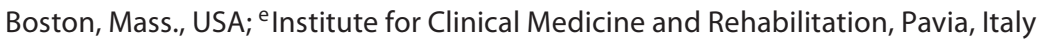

\section{Key Words}

Fish consumption • Prenatal exposure to fine particles •

Cow's milk allergy $\cdot$ Passive tobacco smoke $\cdot$ Cohort study

\begin{abstract}
Background: As there is a scarcity of evidence on potential hazards and preventive factors for infantile eczema operating in the prenatal period, the main goal of this study was to assess the role of prenatal exposure to fine particulate matter and environmental tobacco smoke (ETS) in the occurrence of infant eczema jointly with the possible modulating effect of maternal fish consumption. Methods: The study sample consisted of 469 women enrolled during pregnancy, who gave birth to term babies ( $>36$ weeks of gestation). Among all pregnant women recruited, personal measurements of fine particulate matter $\left(\mathrm{PM}_{2.5}\right)$ were performed over $48 \mathrm{~h}$ in the second trimester of pregnancy. After delivery, every 3 months in the first year of the newborn's life, a detailed, standardized, face-to-face interview was administered to each mother, in the process of which a trained interviewer recorded any history of infantile eczema and data on potential environmental hazards. The estimated risk of eczema related to higher prenatal exposure to fine particulate matter
\end{abstract}

$\left(\mathrm{PM}_{2.5}>53.0 \mu \mathrm{g} / \mathrm{m}^{3}\right)$ and postnatal ETS as well as the protective effect of maternal fish intake were adjusted for potential confounders in a multivariable logistic regression model. $R \boldsymbol{e}$ sults: While the separate effects of higher prenatal $\mathrm{PM}_{2.5}$ and postnatal ETS exposure were not statistically significant, their joint effect appeared to have a significant influence on the occurrence of infantile eczema [odds ratio 2.39 , 95\% confidence interval $(\mathrm{Cl}) 1.10-5.18]$. With maternal fish intake of more than $205 \mathrm{~g} /$ week, the risk of eczema decreased by $43 \%$ (odds ratio $0.57,95 \% \mathrm{Cl} 0.35-0.93$ ). The incidence rate ratio (IRR) for eczema symptoms, estimated from the Poisson regression model, was increased with both higher exposure to prenatal $\mathrm{PM}_{2.5}$ and postnatal ETS (IRR $1.55,95 \% \mathrm{Cl} 0.99-2.44$ ) and in children of atopic mothers (IRR $1.35,95 \% \mathrm{Cl} 1.04-1.75$ ) but was lower in girls (IRR $0.78,95 \% \mathrm{Cl} 0.61-1.00$ ). The observed preventive effect of fish consumption on the frequency of eczema symptoms was consistent with the results of the logistic analysis (IRR $0.72,95 \% \mathrm{Cl} 0.52-0.99$ ). Conclusions: The findings indicate that higher prenatal exposure to fine particulate matter combined with postnatal exposure to ETS may increase the risk of infant eczema, while maternal fish intake during pregnancy may reduce the risk of infantile eczema.

Copyright $\odot 2011$ S. Karger AG, Basel

\section{KARGER}

(c) 2011 S. Karger AG, Basel

Fax +41613061234 E-Mail karger@karger.ch www.karger.com www.karger.com/iaa
Correspondence to: Prof. Wieslaw Jedrychowski

Department of Epidemiology and Preventive Medicine

Jagiellonian University Medical College

7, Kopernika Str., PL-31-034 Krakow (Poland)

Tel. +48 12423 1003, Fax +48 12422 8795, E-Mail myjedryc@ cyf-kr.edu.pl 


\section{Introduction}

While about one third of eczema cases in children manifest during the first year of life and another third during the second year, the remaining one third first appear during later childhood [1-4]. Children with atopic eczema are more likely than those with nonatopic eczema to have their eczema persist into adulthood and are more likely to develop other atopic disorders, primarily asthma. In fact, atopic eczema is often the first manifestation of atopic disease in infancy and is generally considered to be the initial cutaneous manifestation of a systematic disorder that leads to other atopic diseases, including food allergy, asthma and allergic rhinitis, the so-called 'atopic march' [5-9].

The clinical presentation of eczema represents complex interactions between genetic predisposition, the environment, defective skin barrier function and the immunologic response. Although genetic predisposition and allergic sensitization of infants to environmental factors are thought to affect the onset and severity of eczema, a reported rise in the prevalence of eczema over the last several decades suggests an increasing role for the environment in the pathogenesis of infantile eczema. Factors potentially contributing to the rising trend are linked with an increase in traffic-related outdoor pollution, higher allergen exposure, modern housing or an increase in the variety of foods consumed [10-17]. Certain maternal characteristics and a number of perinatal conditions have been found to be important for the development of eczema. While such factors as older maternal age at time of first birth, maternal atopy and active maternal smoking have been identified as possible risk factors for eczema development [18-20], others like breastfeeding appear to protect against it [21-26]. Interestingly, recent studies have shown that maternal fish consumption during pregnancy may modulate the occurrence of eczema in children [27-29].

Because a large proportion of eczema cases occur in the first year of life, it is assumed that eczema may be triggered by environmental factors in the prenatal and perinatal periods in genetically predisposed babies. So far, most studies have focused on defining the factors triggering manifestation of eczema in the postnatal period; many of these studies were based on hospital data that considered only outdoor pollutants and postnatal exposure in older children. As only scarce evidence is available from birth cohort studies on potential hazards and preventive factors for infantile eczema operating in the prenatal period, the main goal of the present study was to assess the role of prenatal exposure to fine particulate air pollution and environmental tobacco smoke (ETS) in the occurrence of infant eczema jointly with the possible modulating effect of maternal fish consumption during pregnancy.

\section{Materials and Methods}

\section{Study Population and Design}

The design of this prospective cohort study and the detailed selection of the population have been described previously [30]. Briefly, this is part of an ongoing comparative longitudinal investigation of the health impact of prenatal exposure to outdoor/indoor air pollution on infants and children being conducted in New York City and Krakow. The study was approved by the Ethical Committee of the Jagiellonian University.

The study involved 505 women who gave birth between 29 and 43 weeks of gestation from January 2001 to February 2004, but the present analysis was restricted to the 469 women who gave birth to term babies ( $>36$ weeks of gestation). The women attending ambulatory prenatal clinics in the first and second trimesters of pregnancy were eligible for the study. The enrollment included only nonsmoking women aged 18-35 years with singleton pregnancies who were free from chronic diseases such as diabetes and hypertension. Upon enrollment, a detailed questionnaire was administered to each subject to solicit information on demographic data, house characteristics, date of the last menstrual period, medical and reproductive history, occupational hazards, alcohol consumption, nutritional habits and smoking practices of others present in the home. After delivery, every 3 months in the first year of the newborn's life, a detailed, standardized, face-to-face interview on the infant's health was administered to each mother by a trained interviewer. During the interview at each of the study periods 3, 6, 9 and 12 months after birth, a history of infantile eczema was recorded if the child experienced dry skin in combination with itchy rash and typical localization, which were confirmed by a physician. Gestational age at birth denotes the interval between the last day of the mother's last menstrual period and the date of birth, and exclusive breastfeeding defines the period during which the infants were given only breast milk, and no formula, cow's milk or solid foods had been introduced. Maternal atopy was defined as a reported medical diagnosis of eczema, asthma or hay fever. Data on the number of cigarettes smoked daily by all household members were used to assess ETS at home during the prenatal and postnatal periods. The identification of a home with mold problems was based on the responses to questions concerning visible patches of mold growth on the internal humid walls of the household.

Dosimetry of Prenatal Personal Exposure to Fine Particles

During the second trimester, a member of the air monitoring staff instructed each woman in the study how to use the personal environmental monitoring sampler, a lightweight, quiet device worn in a backpack. The woman was asked to wear the monitor during the daytime hours for 2 consecutive days and to place the monitor near the bed at night. During the morning of the second day, the air monitoring staff member and interviewer visited the 
woman's home to change the battery pack and administer the full questionnaire. They also checked whether the monitor had been running continuously without any technical or operating failures. A staff member returned to the woman's home on the morning of the third day to pick up the equipment.

The personal environmental monitoring sampler was designed to achieve the particle target size of $\leq 2.5 \mu \mathrm{m}$ at a flow rate of 4.0 liters/min with an array of 10 impactor nozzles. Flow rates are calibrated (with filters in place) using a bubble meter prior to the monitoring and are checked again with the change of the battery pack on the second day and at the conclusion of the monitoring. Pumps operated continuously at 2 liters/min over the 48 -hour period. To modify the sampler to achieve the $2.5-\mu \mathrm{m}$ size cutoff at 2 liters/min, 5 of the nozzles were blocked. Particles were collected on a Teflon membrane filter (37-mm Teflon; Gelman Sciences). The combination of low pressure drop (permitting use of a low-power sampling pump), low hygroscopicity (minimizing bound water interference in mass measurements) and low trace element background (improving analytical sensitivity) of these filters makes them highly appropriate for personal particle sampling.

To evaluate the correlation between the level of $\mathrm{PM}_{2.5}$ measured over $48 \mathrm{~h}$ in the second trimester of pregnancy with those in the first and the third trimesters, a series of repeated measurements in each trimester was carried out in a subsample of 80 pregnant women who were recruited in the first trimester. The mean concentration of $\mathrm{PM}_{2.5}$ in the second trimester was $44.4 \mu \mathrm{g} / \mathrm{m}^{3}$ (SD 46.5), which was not significantly different from the mean concentration in the first $\left(46.2 \mu \mathrm{g} / \mathrm{m}^{3}\right.$, SD 34.0) and third trimester $\left(35.9 \mu \mathrm{g} / \mathrm{m}^{3}\right.$, SD 35.3). This provides some confidence that the measurements of total personal level of exposure to fine particles taken in the second trimester may be representative of other pregnancy periods.

\section{Assessment of Maternal Fish Intake}

Food frequency questionnaires (FFQs) were administered by trained interviewers twice during the gestation period (in the second and third trimester of pregnancy). In the course of the food interviews, detailed information on the eating frequency of smoked, fried, roasted and grilled fish servings was also collected. Maternal fish intake was categorized as follows: never; less than once per month; once per week; 1-2 times per week; 3-4 times per week, or every day. To estimate the total amount of fish eaten per week, it was assumed that each fish meal averaged $150 \mathrm{~g}$.

\section{Statistical Methods}

In the statistical analysis of the data, logistic and Poisson multivariable regressions were used to analyze the relationship between infantile eczema and the main exposure variables, i.e. individual prenatal exposure to fine particles (dichotomized by the third quartile cutoff point, i.e. $53.0 \mu \mathrm{g} / \mathrm{m}^{3}$ ), prenatal and postnatal ETS, and maternal fish consumption (coded as tertiles of intake). In the logistic regression model, the risk of infantile eczema due to environmental pollutants and maternal consumption of fish was adjusted for a set of potential confounders including maternal characteristics (age, education, atopy), duration of exclusive breastfeeding, presence of older siblings and damp/moldy house. In order to evaluate the relationship between the frequency of infantile eczema (measured by the number of time points at which symptoms were reported) and potential preventive and risk fac-
Table 1. Maternal characteristics of the study sample grouped according to the reported diagnosis of infantile eczema

\begin{tabular}{|c|c|c|c|}
\hline Variables & $\begin{array}{l}\text { Eczema }(-) \\
(\mathrm{n}=286)\end{array}$ & $\begin{array}{l}\text { Eczema }(+) \\
(\mathrm{n}=183)\end{array}$ & $\mathrm{p}$ value \\
\hline Maternal age, years & $27.59 \pm 3.53$ & $27.66 \pm 3.56$ & 0.839 \\
\hline \multicolumn{4}{|l|}{ Maternal education } \\
\hline years of schooling & $15.5 \pm 2.8$ & $15.8 \pm 2.5$ & 0.126 \\
\hline Maternal atopy $(+)$ & $67(23.4)$ & $47(25.7)$ & 0.656 \\
\hline \multicolumn{4}{|l|}{ Parity } \\
\hline 1 & $179(62.6)$ & $117(63.9)$ & 0.844 \\
\hline$\geq 2$ & $107(37.4)$ & $66(36.1)$ & \\
\hline Humid house & $29(10.1)$ & $26(14.2)$ & 0.235 \\
\hline Mold in house & $23(8.0)$ & $17(9.3)$ & 0.762 \\
\hline $\mathrm{PM}_{2.5}$ in pregnancy, $\mu \mathrm{g} / \mathrm{m}^{3}$ & $42.23 \pm 30.28$ & $45.40 \pm 42.71$ & 0.349 \\
\hline \multicolumn{4}{|c|}{ Fish consumption during third trimester } \\
\hline$\leq 90 \mathrm{~g} /$ week & $100(35.0)$ & $76(41.5)$ & 0.065 \\
\hline 91-205 g/week & $99(34.6)$ & $69(37.7)$ & \\
\hline$>205 \mathrm{~g} /$ week & $87(30.4)$ & $38(20.8)$ & \\
\hline
\end{tabular}

Values represent means \pm SD or numbers of patients with percentages in parentheses, as appropriate.

tors, Poisson multivariable regression was used with the same set of main exposure variables and confounders as above. In all statistical analyses, which were performed with the statistical software Stata (version 11), the significance level was assumed as $\mathrm{p}<$ 0.05 .

\section{Results}

Tables 1 and 2 show the characteristics of the mothers and infants grouped according to the presence of infantile eczema reported sometime in the four 3-month intervals over the follow-up period. They show that the characteristics of mothers and infants were similar across the groups, except for maternal fish consumption. The cumulative prevalence of eczema at 1 year of age was $39 \%$ [95\% confidence interval (CI) 34.4-43.2\%]; 25\% presented with symptoms only in 1 study period, and $14 \%$ of children presented with symptoms in 2 or more periods. The highest prevalence of infantile eczema was observed in those who were exposed jointly to $\mathrm{PM}_{2.5}$ and postnatal ETS, and the lowest prevalence was observed in infants of mothers with higher maternal fish intake (table 3 ).

The analysis of personal air samples collected from pregnant women in the second pregnancy trimester showed a median concentration of prenatal $\mathrm{PM}_{2.5}$ of $34.8 \mu \mathrm{g} / \mathrm{m}^{3}$ (interquartile range of $29.8 \mu \mathrm{g} / \mathrm{m}^{3}$ ), with one third of children being exposed to $\mathrm{PM}_{2.5}$ above 53.0 
Table 2. Characteristics of the infants under study grouped according to the reported diagnosis of infantile eczema

\begin{tabular}{lccc}
\hline Variables & $\begin{array}{l}\text { Eczema (-) } \\
(\mathrm{n}=286)\end{array}$ & $\begin{array}{l}\text { Eczema (+) } \\
(\mathrm{n}=183)\end{array}$ & p value \\
\hline Gender & $137(47.9)$ & $100(54.6)$ & 0.184 \\
$\quad$ Boys $\quad 149(52.1)$ & $83(45.4)$ & 0.651 \\
$\quad$ Girls & $39.51 \pm 1.157$ & $39.56 \pm 1.117$ & 0.737 \\
Gestational age, weeks & $3,449.0 \pm 452.7$ & $3,435.1 \pm 406.8$ & 0.928 \\
Lirth weight, g & $54.75 \pm 2.712$ & $54.77 \pm 2.370$ & 0.404 \\
Hength at birth, cm & $33.87 \pm 1.431$ & $33.98 \pm 1.311$ & 0.654 \\
Exclusive breastfeeding $>3$ months & $138(48.3)$ & $93(50.8)$ & 0.712 \\
Prenatal ETS exposure & $74(25.9)$ & $51(27.9)$ & 0.196 \\
Postnatal ETS exposure & $35(12.2)$ & $31(16.9)$ & \\
\hline
\end{tabular}

Values represent means \pm SD or numbers of patients with percentages in parentheses, as appropriate.

Table 3. Observed prevalence of infantile eczema as reported by mothers at any stage during the follow-up (grouped by various potential risk factors)

\begin{tabular}{|c|c|c|}
\hline Variables & $\begin{array}{l}\text { Prevalence } \\
\%\end{array}$ & $95 \% \mathrm{CI}$ \\
\hline Prenatal or postnatal ETS alone & 42.1 & $32.9-51.7$ \\
\hline Higher $\mathrm{PM}_{2.5}$ alone & 38.8 & $25.2-53.4$ \\
\hline Postnatal ETS and higher $\mathrm{PM}_{2.5}$ & 54.6 & $36.6-72.5$ \\
\hline Fish intake $\leq 90 \mathrm{~g} /$ week & 43.2 & $35.8-50.6$ \\
\hline Fish intake $91-205 \mathrm{~g} /$ week & 41.1 & $33.6-48.6$ \\
\hline Fish intake $>205 \mathrm{~g} /$ week & 30.4 & $22.2-38.6$ \\
\hline
\end{tabular}

$\mu \mathrm{g} / \mathrm{m}^{3}$. While $27 \%$ of infants were exposed to prenatal ETS, only $14.1 \%$ of them were reported to be exposed postnatally to ETS at home in the first year of life. There was a significant correlation between prenatal $\mathrm{PM}_{2.5}$ concentrations and the reported number of cigarettes smoked daily by household members during the pregnancy period (Spearman correlation $=0.212, \mathrm{p}<0.001$ ). Mean concentrations of $\mathrm{PM}_{2.5}$ were significantly higher among infants with reported prenatal ETS (53.9 vs. 40.3 $\left.\mu \mathrm{g} / \mathrm{m}^{3} ; \mathrm{p}=0.0002\right)$.

On average, mothers of infants with diagnosed eczema consumed a significantly lower amount of fish during pregnancy, and there was a significant inverse trend of eczema prevalence with the tertiles of fish consumption (nonparametric trend: $\mathrm{z}=-2.16, \mathrm{p}=0.03$ ). The pattern of fish consumption was related neither to maternal characteristics such as education $\left[\chi^{2}(4)=2.219, p=0.696\right]$ nor
Table 4. Comparison of effects of prenatal exposure to fine particulate matter and postnatal ETS with the protective effect of fish consumption in pregnancy on eczema symptoms occurring at any stage during the first year life

\begin{tabular}{|c|c|c|c|c|c|}
\hline \multicolumn{2}{|c|}{ Predictors } & \multirow{2}{*}{$\begin{array}{l}\text { Odds } \\
\text { ratio }\end{array}$} & \multirow[t]{2}{*}{$\mathrm{z}$} & \multirow[t]{2}{*}{$\mathrm{p}>\mathrm{z}$} & \multirow[t]{2}{*}{$95 \% \mathrm{CI}$} \\
\hline $\begin{array}{l}\text { postnatal } \\
\text { ETS }^{\mathrm{a}}\end{array}$ & $\mathrm{PM}_{2.5}{ }^{\mathrm{b}}$ & & & & \\
\hline- & - & 1.00 & ref. & & \\
\hline- & + & 1.08 & 0.32 & 0.749 & $0.67-1.74$ \\
\hline+ & - & 1.13 & 0.31 & 0.758 & $0.53-2.42$ \\
\hline+ & + & 2.39 & 2.21 & 0.027 & $1.10-5.18$ \\
\hline \multicolumn{6}{|c|}{ Fish consumption in pregnancy } \\
\hline \multirow{3}{*}{\multicolumn{2}{|c|}{$\begin{array}{l}\leq 90 \text { g per week } \\
91-205 \text { g per week } \\
>205 \text { g per week }\end{array}$}} & 1.00 & ref. (l) & & \\
\hline & & 0.91 & -0.41 & 0.678 & $0.59-1.41$ \\
\hline & & 0.57 & -2.25 & 0.025 & $0.35-0.93$ \\
\hline
\end{tabular}

Regression estimates additionally adjusted for gender of the child, maternal age and education, maternal atopy, older siblings, exclusive breastfeeding $>3$ months and damp house. Ref. $=$ Reference value.

${ }^{\text {a }}$ Postnatal ETS: 0 = no smoking at home; 1 = reported cigarette smoking by at least one household member.

${ }^{\mathrm{b}}$ Prenatal $\mathrm{PM}_{2.5}: 0=\mathrm{PM}_{2.5} \leq 53 \mu \mathrm{g} / \mathrm{m}^{3} ; 1=\mathrm{PM}_{2.5}>53 \mu \mathrm{g} / \mathrm{m}^{3}$.

maternal age at delivery $\left[\chi^{2}(4)=4.3658, \mathrm{p}=0.359\right]$ nor maternal atopy $\left[\chi^{2}(2)=0.3038, p=0.859\right]$.

Using the logistic multivariable regression model, we estimated the risk of eczema (odds ratio) related to prenatal exposure to fine particulate matter and postnatal ETS, as well as the protective effect of maternal fish intake 
Table 5. Poisson regression model for the frequency of infantile eczema reported in the follow-up period related to ambient hazards and maternal fish intake

\begin{tabular}{lcrcl}
\hline Predictors & IRR & $\mathrm{z}$ & $\mathrm{p}>\mathrm{z}$ & \multicolumn{1}{c}{$95 \% \mathrm{CI}$} \\
\hline Maternal atopy (yes/no) & 1.35 & 2.22 & 0.026 & $1.04-1.75$ \\
Gender of child (girls) & 0.78 & -1.98 & 0.048 & $0.61-1.00$
\end{tabular}

Postnatal ${ }^{\mathrm{a}} \quad \mathrm{PM}_{2.5}{ }^{\mathrm{b}}$

ETS

\begin{tabular}{lllrrr}
\hline- & - & 1.00 & ref. & & \\
- & + & 1.13 & 0.78 & 0.437 & $0.84-1.51$ \\
+ & - & 0.88 & -0.46 & 0.643 & $0.52-1.49$ \\
+ & + & 1.55 & 1.89 & 0.058 & $0.99-2.44$ \\
\hline
\end{tabular}

Fish consumption in pregnancy

$\leq 90$ g per week $\quad 1.00$

91-205 g per week $\quad 1.03$

$>205$ g per week

0.72

ref.

$0.19 \quad 0.848 \quad 0.78-1.35$

$\begin{array}{lll}-1.99 & 0.047 \quad 0.52-0.99\end{array}$

Regression estimates additionally adjusted for maternal age, education, exclusive breastfeeding $>3$ months and damp house. Ref. $=$ Reference value.

${ }^{\text {a }}$ Postnatal ETS: 0 = no smoking at home; 1 = reported cigarette smoking by at least one household member.

${ }^{\mathrm{b}}$ Prenatal $\mathrm{PM}_{2.5}$ exposure: $0=\mathrm{PM}_{2.5} \leq 53 \mu \mathrm{g} / \mathrm{m}^{3} ; 1=\mathrm{PM}_{2.5}>53$ $\mu \mathrm{g} / \mathrm{m}^{3}$.

after adjusting for the set of potential confounders (table 4). In the regression analysis, prenatal ETS was dropped from the model due to its collinearity with the $\mathrm{PM}_{2.5}$ variable. While the separate effects of prenatal $\mathrm{PM}_{2.5}$ and postnatal ETS were not statistically significant, their joint effect appeared to have a significant influence on the onset of infantile eczema (odds ratio 2.39, 95\% CI 1.10-5.18). With maternal fish intake of more than $205 \mathrm{~g} /$ week, the risk of eczema decreased by $43 \%$ (odds ratio $0.57,95 \%$ CI $0.35-0.93$ ).

Poisson multivariable regression was used in the assessment of the incidence rate ratio (IRR) of the frequency of eczema recorded in the follow-up. As before, the association between the frequency of eczema symptoms and exposure variables was adjusted for the same set of confounding variables that were applied in the logistic multivariable analysis. The results of the Poisson regression model (table 5) show that the IRR for the frequency of eczema symptoms was borderline increased in the group of children with joint higher prenatal $\mathrm{PM}_{2.5}$ (above 53.0 $\mu \mathrm{g} / \mathrm{m}^{3}$ ) and postnatal ETS (IRR 1.55, 95\% CI 0.99-2.44) and in those whose mothers were atopic (IRR 1.35, 95\% CI 1.04-1.75), but was lower in girls (IRR 0.78, 95\% CI 0.61-
1.00). The observed preventive effect of fish consumption on eczema symptoms was consistent with the results of the logistic analysis (IRR 0.72, 95\% CI 0.52-0.99).

\section{Discussion}

In the present study, we found that joint higher prenatal exposure to fine particulate matter and postnatal ETS doubled the risk of eczema symptoms occurring at any point in the first year life. From the other perspective, our findings have shown that a higher maternal fish intake in pregnancy had a protective effect on the risk and frequency of infantile eczema. The adjusted preventive effect of fish consumed in pregnancy could only be demonstrated at the higher level of fish intake (>205 g/week), which may suggest a threshold below which the preventive effect is irrelevant. To our knowledge, there have been no other studies that have considered the effects of prenatal exposure to fine particles and postnatal ETS on infantile eczema in the context of the preventive effect of maternal fish intake.

Fish intake during pregnancy may have potential benefits for healthy fetal development as it is a rich source of long-chain polyunsaturated fatty acids (PUFAs), including eicosapentaenoic and docosahexaenoic acids, which are necessary for the healthy development of fetal tissues. PUFAs are important constituents of cells, where they play a role in membrane protein function, maintenance of membrane fluidity and regulating gene expression and cellular function [31, 32]. In addition, there is evidence that PUFAs can modulate immune responses affecting the production of key inflammatory cytokines and the Th1 versus Th2 balance, thereby exerting beneficial effects in a variety of inflammatory diseases such as allergic diseases, asthma, atherosclerosis-related cardiovascular diseases or psoriasis. A number of molecular mechanisms have been postulated to explain how PUFAs could interfere with immune cell function [33-39]. Alternatively, fish intake may be a marker of some other maternal or infantile characteristics not considered in our study that are associated with the healthy development of babies (for instance quality of maternal care, other nutritional factors or housing).

The biological mechanisms whereby prenatal $\mathrm{PM}_{2.5}$ might cause infantile eczema are still unclear. Ambient fine particulate matter contains a whole complex of toxic agents that could adversely affect fetal development. Typically, the $\mathrm{PM}_{2.5}$ fraction contains constituents of soot including polycyclic aromatic hydrocarbons (PAHs), tobacco and wood smoke, traffic exhaust containing organic compounds, sulfates and metals [40]. Transplacental ex- 
posure to PAHs from maternal inhalation can produce cytotoxic reactive oxygen species that ultimately induce inflammatory and oxidant stress responses [41], cause disruptions to the endocrine system and lead to disturbances of the pituitary-adrenocortico-placental system [42]. Formation of PAH adducts may induce the activation of apoptosis [43] or the binding to receptors of placental growth factors [44], resulting in the decreased exchange of oxygen and nutrients and possibly enhancing the production of $\operatorname{IgE}$ antibodies and Th2 cytokines. It may be hypothesized that postnatal exposure of infants to environmental pollutants may strengthen the effect of the prenatal exposure to fine particulate matter, possibly by damaging the infantile skin barrier function and the postnatal development of new skin cells.

Some weakness in our study could have resulted from the possible maternal reporting bias of the medical diagnosis of skin disorders in the children under study; however, a differential bias in reporting a medical diagnosis of eczema between the exposed and nonexposed infants is not likely to occur since the children being compared did not differ in terms of maternal education and access to medical care. Our data on fish consumption were based on the FFQ method, which is useful for ranking individuals but does not necessarily permit confident assessments of absolute intake. The FFQ method can be subject to systematic errors in reporting, and therefore our results must be interpreted cautiously. Moreover, the portion sizes were not weighed but approximated, and information on the type of fish consumed by the study participants was not collected.
On the other hand, the major strength of our study is the fact that the study sample of infants belonged to a lowrisk group recruited from an urban community. However, the birth cohort differed from the broader population in several respects as the study excluded women with conditions that could have affected the health of the babies, such as active maternal cigarette smoking, multiple pregnancy or preexisting chronic diseases. One strength of our study is the careful prospective monitoring of eczema symptoms by regular interviews performed at 3-month intervals, as well as the accurate personal prenatal exposure assessments of fine particulate matter and ETS exposure in the perinatal period, which had not been taken into account in previous studies on infantile eczema. Our assessment of total personal individual exposure to fine particulate pollutants included all potential sources of exposure during pregnancy, both indoors and outdoors.

In conclusion, our findings indicate that high prenatal exposure to fine particulate matter combined with postnatal exposure to ETS may increase the risk of infantile eczema, while maternal fish intake in pregnancy may reduce the risk of infantile eczema. If replicated, the results of this study may have important preventive implications for the health of babies and older children as well.

\section{Acknowledgments}

This study received funding from an $\mathrm{RO} 1$ grant entitled 'Vulnerability of the Fetus/Infant to $\mathrm{PAH}, \mathrm{PM}_{2.5}$ and ETS' (5 RO1 ES10165 NIEHS; 02/01/00-01/31/04) and The Gladys and Roland Harriman Foundation, New York.

\section{References}

1 Williams HC: Epidemiology of atopic dermatitis. Clin Exp Dermatol 2000;25:522529.

- Wadonda-Kabondo N, Sterne JA, Golding J, Kennedy CT, Archer CB, Dunnill MG; ALSPAC Study Team: A prospective study of the prevalence and incidence of atopic dermatitis in children aged 0-42 months. Br J Dermatol 2003; 149:1023-1028.

- 3 Asher MI, Montefort S, Björkstèn B, Lai CK, Strachan DP, Weiland SK, Williams H; ISAAC Phase Three Study Group: Worldwide time trends in the prevalence of symptoms of asthma, allergic rhinoconjunctivitis, and eczema in childhood: ISAAC Phases One and Three repeated multicountry crosssectional surveys. Lancet 2006;368:733-743.
-4 Kay J, Gawkrodger DJ, Mortimer MJ, Jaron AG: The prevalence of childhood atopic eczema in a general population. J Am Acad Dermatol 1994;30:35-39.

5 Illi S, von Mutius E, Lau S, Nickel R, Grüber C, Niggemann B, Wahn U; Multicenter Allergy Study Group: The natural course of atopic dermatitis from birth to age 7 years and the association with asthma. J Allergy Clin Immunol 2004;113:925-931.

-6 Spergel JM, Paller AS: Atopic dermatitis and the atopic march. J Allergy Clin Immunol 2003;112(6 suppl):S118-S127.

-7 Bergmann RL, Edenharter G, Bergmann KE, Forster J, Bauer CP, Wahn V, Zepp F, Wahn U: Atopic dermatitis in early infancy predicts allergic airway disease at 5 years. Clin Exp Allergy 1998;28:965-970.
8 Businco L, Falconieri P, Di Rienzo A, Bruno G: From atopic dermatitis to asthma: the risk factors and preventive measures. Pediatr Pulmonol Suppl 1997;16:19-20.

9 van der Hulst AE, Klip H, Brand PL: Risk of developing asthma in young children with atopic eczema: a systematic review. J Allergy Clin Immunol 2007;120:565-569.

10 Strachan DP: Time trends in asthma and allergy: ten questions, fewer answers. Clin Exp Allergy 1995;25:791-794.

- 11 Krämer U, Sugiri D, Ranft U, Krutmann J, von Berg A, Berdel D, Behrendt H, Kuhlbusch T, Hochadel M, Wichmann HE, Heinrich J; GINIplus and LISAplus study groups: Eczema, respiratory allergies, and traffic-related air pollution in birth cohorts from small-town areas. J Dermatol Sci 2009;56: 99-105. 
-12 Bisgaard H, Halkjaer LB, Hinge R, Giwercman C, Palmer C, Silveira L, Strand M: Risk analysis of early childhood eczema. J Allergy Clin Immunol 2009;123:1355-1360.e5.

13 Kjellman NI, Nilsson L: From food allergy and atopic dermatitis to respiratory allergy. Pediatr Allergy Immunol 1998;9(11 suppl):13-17.

14 Krämer U, Weidinger S, Darsow U, Möhrenschlager M, Ring J, Behrendt H: Seasonality in symptom severity influenced by temperature or grass pollen: results of a panel study in children with eczema. J Invest Dermatol 2005;24:514-523.

15 Lannerö E, Kull I, Wickman M, Pershagen G, Nordvall SL: Environmental risk factors for allergy and socioeconomic status in a birth cohort (BAMSE). Pediatr Allergy Immunol 2002;13:182-187.

-16 Sicherer SH, Sampson HA: Food hypersensitivity and atopic dermatitis: pathophysiology, epidemiology, diagnosis, and management. J Allergy Clin Immunol 1999; 104:S114-S122.

17 Gustafsson D, Sjöeberg O, Foucard T: Development of allergies and asthma in infants and young children with atopic dermatitis a prospective follow-up to 7 years of age. Allergy 2000;55:240-245.

- 18 Moore MM, Rifas-Shiman SL, Rich-Edwards JW, Kleinman KP, Camargo CA Jr, Gold DR, Weiss ST, Gillman MW: Perinatal predictors of atopic dermatitis occurring in the first six months of life. Pediatrics 2004; 113:468-474.

-19 Schäfer T, Dirschedl P, Kunz B, Ring J, Uberla K: Maternal smoking during pregnancy and lactation increases the risk for atopic eczema in the offspring. J Am Acad Dermatol 1997;36:550-556.

>20 Böhme M, Wickman M, Lennart Nordvall S, Svartengren M, Wahlgren CF: Family history and risk of atopic dermatitis in children up to 4 years. Clin Exp Allergy 2003;33:12261231.

-21 Hanson L, Silfverdal SA, Strömbäck L, Erling V, Zaman S, Olcén P, Telemo E: The immunological role of breast feeding. Pediatr Allergy Immunol 2001;12(suppl 14):15-19.
22 Goldman AS, Hopkinson JM, Rassin DK: Benefits and risks of breastfeeding. Adv Pediatr 2007;54:275-304.

23 van Odijk J, Kull I, Borres MP, Brandtzaeg P, Edberg U, Hanson LA, Høst A, Kuitunen M, Olsen SF, Skerfving S, Sundell J, Wille S: Breastfeeding and allergic disease: a multidisciplinary review of the literature (19662001) on the mode of early feeding in infancy and its impact on later atopic manifestations. Allergy 2003;58:833-843.

24 Kull I, Böhme M, Wahlgren CF, Nordvall L, Pershagen G, Wickman M: Breast-feeding reduces the risk for childhood eczema. J Allergy Clin Immunol 2005;116:657-661.

25 Lowe AJ, Carlin JB, Bennett CM, Abramson MJ, Hosking CS, Hill DJ, Dharmage SC: Atopic disease and breastfeeding - cause or consequence? J Allergy Clin Immunol 2006; 117:682-687.

26 Sears MR, Greene JM, Willan AR, Taylor DR, Flannery EM, Cowan JO, Herbison GP, Poulton R: Long-term relation between breastfeeding and development of atopy and asthma in children and young adults: a longitudinal study. Lancet 2002;360:901-907.

27 Stulnig TM: Immunomodulation by polyunsaturated fatty acids: mechanisms and ef fects. Int Arch Allergy Immunol 2003;132: 310-321.

28 Dunstan J, Mori TA, Barden A, Beilin LJ, Taylor AL, Holt PG, Prescott SL: Fish oil supplementation in pregnancy modifies neonatal allergen-specific immune responses and clinical outcomes in infants at high risk of atopy: a randomized controlled trial. J Allergy Clin Immunol 2003;112:1178-1184

29 Romieu I, Torrent M, Garcia-Esteban R, Ferrer C, Ribas-Fitó N, Antó JM, Sunyer J: Maternal fish intake during pregnancy and atopy and asthma in infancy. Clin Exp Allergy 2007;37:518-525.

30 Jedrychowski W, Whyatt RM, Camann DE, Bawle UV, Peki K, Spengler JD, Dumyahn TS, Penar A, Perera FF: Effect of prenatal $\mathrm{PAH}$ exposure on birth outcomes and neurocognitive development in a cohort of newborns in Poland. Study design and preliminary ambient data. Int J Occup Med Environ Health 2003;16:21-29.

31 Connor WE: Importance of n-3 fatty acids in health and disease. Am J Clin Nutr 2000;71 (1 suppl):171S-175S.
32 Simopoulos AP: Omega-3 fatty acids in health and disease and in growth and development. Am J Clin Nutr 1991;54:438-463.

33 Prescott SL, Calder PC: N-3 polyunsaturated fatty acids and allergic disease. Curr Opin Clin Nutr Metab Care 2004;7:123-129.

34 Calder PC: N-3 polyunsaturated fatty acids and inflammation: from molecular biology to the clinic. Lipids 2003;38:343-352.

-35 Vachier I, Chanez P, Bonnans C, Godard P, Bousquet J, Chavis C: Endogenous anti-inflammatory mediators from arachidonate in human neutrophils. Biochem Biophys Res Commun 2002;290:219-224.

-36 Sanderson P, MacPherson GG, Jenkins CH, Calder PC: Dietary fish oil diminishes the antigen presentation activity of rat dendritic cells. J Leukoc Biol 1997;62:771-777.

$\checkmark 37$ Calder PC, Miles EA: Fatty acids and atopic disease. Pediatr Allergy Immunol 2000; 11(suppl 13):29-36.

38 Duchén K, Björkstén B: Polyunsaturated n-3 fatty acids and the development of atopic disease. Lipids 2001;36:1033-1042.

$>39$ Calder PC: N-3 polyunsaturated fatty acids and cytokine production in health and disease. Ann Nutr Metab 1997;41:203-234.

40 Spengler JD, Samet JM, McCarthy JF: Indoor Air Quality Handbook. New York, McGrawHill, 2001.

41 Donaldson K, Stone V, Borm PJ, Jimenez LA, Gilmour PS, Schins RP, Knaapen AM, Rahman I, Faux SP, Brown DM, MacNee W: Oxidative stress and calcium signaling in the adverse effects of environmental particles (PM10). Free Radic Biol Med 2003;34:13691382.

42 Wilhelm M, Ritz B: Residential proximity to traffic and adverse birth outcomes in Los Angeles county, California, 1994-1996. Environ Health Perspect 2003;111:207-216.

43 Wood KA, Youle RJ: The role of free radicals and p53 in neuron apoptosis in vivo. J Neurosci 1995; 15:5851-5857.

44 Dejmek J, Solanský I, Benes I, Lenícek J, Srám RJ: The impact of polycyclic aromatic hydrocarbons and fine particles on pregnancy outcome. Environ Health Perspect 2000; 108:1159-1164. 